\title{
DESAIN SISTEM KONTROL PENYALAAN LAMPU DAN PERANGKAT ELEKTRONIK UNTUK MENIRU KEBERADAAN PENGHUNI RUMAH
}

\author{
Zulfikar*, Zulhelmi, Khairul Amri \\ Jurusan Teknik Elektro, Fakultas Teknik, Universitas Syiah Kuala \\ Jl. Tgk. Syech Abdul Rauf No. 7, Darussalam, Banda Aceh, Indonesia \\ *Corresponding author, e-mail : zulfikarsafrina@unsyiah.ac.id
}

\begin{abstract}
Abstrak-Pada penelitian ini dirancang sebuah sistem kontrol penyalaan lampu dan perangkat elektronik untuk meniru keberadaan penghuni rumah. Sistem dirancang untuk mengontrol penyalaan beberapa lampu dan perangkat elektronik secara acak. Hal tersebut bertujuan untuk menimbulkan kesan bahwa rumah yang ditinggalkan seakan akan ada penghuninya. Sistem keamanan ini bekerja dengan cara membangkitkan sebuah bilangan acak setiap 15 menit. Setiap bilangan acak yang dibangkitkan mengacu kepada peralatan listrik yang dikontrol. Peralatan listrik rumah yang telah menyala akan padam ketika lamanya waktu yang ditetapkan tercapai. Sistem yang dirancang terdiri dari Arduino, catu daya, RTC dan interface perantara dengan peralatan listrik. Sistem telah diuji selama 5 hari waktu normalisasi terhadap sistem kontrolnya dan sistem miniatur rumah. Miniatur rumah dibuat untuk mewakili kondisi rumah yang sebenarnya. Konsumsi daya listrik perhari dari sistem yang dibuat adalah $0,42 \mathrm{kWh}$.
\end{abstract}

\section{Kata Kunci : Arduino, Bilangan Acak, Peralatan Listrik, Sistem Kontrol, Keamanan Rumah}

\begin{abstract}
This paper proposes a system for controlling bulbs and electrical appliances in order to imitate the availability of the owner in a house. The designed system is able to turn on and turn off the equipments randomly for treating the availability of the owners in their houses. The system generates a number randomly every 15 minutes. Each number associated with bulb or electrical device in the controlling list. The electrical devices will be ON or OFF based on specific duration times. The system is realized using an Arduino board, an RTC, power supply unit, and interface circuit of Arduino and electrical devices. The designed system has been tested for 5 consecutive days normalized to 2 hour normal time on the control device and house miniature. The miniature is used to mimic condition the real house. Electric consumption estimated about $0.42 \mathrm{kWh}$ per day
\end{abstract}

Keywords : Arduino, Random Numbers, Electrical Appliances, Control Systems, Housing Security

Copyright $\odot 2016$ JNTE. All rights reserved

\section{PENDAhuluan}

Aktivitas di luar rumah yang semakin padat mengharuskan orang untuk meninggalkan rumahnya dalam keadaan kosong. Oleh karena itu saat malam hari rumah menjadi gelap dan pada siang harinya menjadi sepi dan sunyi. Keadaan seperti ini dapat menimbulkan peluang bagi pencuri mengincar rumah tersebut, sehingga menjadi tidak aman. Untuk mencegah hal tersebut terjadi maka pemilik rumah dapat memasang sistem keamanan pada rumahnya.

Salah satu sistem keamanan yang dapat digunakan adalah sistem keamanan yang mampu memberi kesan adanya penghuni rumah. Sebagai contoh, sistem keamananan dengan penyalaan peralatan listrik memlalui jarak jauh. Sistem ini bekerja ketika pemilik rumah mengirimkan sinyal isyarat dengan menekan tombol telepon (telepon kabel). Pemilik rumah dapat menyalakan lampu pada malam hari dan mematikannya pada siang hari walaupun tidak berada di rumah [1].

Sistem keamanan lainnya yang telah dibuat adalah sistem yang dapat diakses dari jarak jauh dengan handphone. Sistem ini bekerja dengan mengirimkan pesan ke handphone lain yang ada di rumah. Pesan tersebut berisi perintah untuk menyalakan atau memadamkan lampu. Pada sistem ini terdapat output feedback berupa sensor cahaya. Tujuan pemasangan sensor tersebut adalah untuk memberi informasi kepada pemilik rumah bahwa lampu yang dinyalakan benar-benar telah menyala [2],[3]. 
Sistem-sistem tersebut mempunyai kelemahan, diantaranya adalah adanya gangguan yang terjadi pada jaringan seluler dan kelupaan memberikan perintah untuk memadamkan peralatan listrik secara teratur. Hal tersebut menyebabkan sebagian peralatan listrik menyala terus-menerus. Oleh karena itu diperlukan suatu alat yang mampu meniru kondisi rumah berpenghuni ketika rumah tersebut ditinggalkan pemiliknya. Hal tersebut bertujuan untuk mengelabui pencuri sehingga rumah terhindar dari tindakan pencurian.

Penelitian ini merancang suatu sistem keamanan rumah secara otomatis. Sistem ini dapat menyalakan peralatan listrik berupa lampu-lampu ruangan dan juga peralatan elektronik secara acak. Sistem yang di desain juga bisa membedakan kondisi siang dan malam, sehingga kondisi penyalaan dapat dibedakan. Pada bagian teori akan disajikan prinsip dasar dari pembangkitan bilangan acak, sistem kontrol dan RTC. Desain sistem kontrol akan disajikan pada bagian 3. Hasil dan pembahasannya disajikan pada bagian 4 , dan kesimpulan pada bagian akhir.

\section{TINJAUAN PUSTAKA}

\subsection{Bilangan Acak}

Suatu bilangan yang tidak dapat diprekdisi kemunculannya disebut dengan bilangan acak/ random. Untuk membangkitkan bilangan random pada komputer maka diperlukan sebuah IDE compiler. IDE ini berfungsi untuk menerjemahkan program yang telah dibuat ke dalam bahasa mesin, sehingga komputer dapat menjalankan program tersebut.

Ada beberapa algoritma pembangkit bilangan random atau pseudo random number yang digunakan seperti LCG (Linear Congruential Generators), MRNG (Multiplicative Random Number Generator) dan MCRNG (Mixed Congruential Random Number Generator). LCG merupakan metode yang digunakan untuk membangkitkan bilangan random dengan distribusi uniform. MRNG adalah metode pembangkitan bilangan random berupa bilangan-bilangan prima. Untuk MCRNG sama seperti LCG, hanya saja jika digunakan bilangan nol sebagai nilai acuannya maka sistemnya menjadi error. Maka dari itu, untuk pembangkitan bilangan random yang paling baik digunakan adalah LCG, karena nilai acuannya tidak ditentukan dan bisa digunakan bilangan apa saja [4].

\subsection{Arduino}

Arduino merupakan platform open source baik secara hardware maupun software. Mikrokontroler yang terdapat pada Arduino memiliki beberapa jenis seperti ATmega8, ATmega328, ATmega1280 dan ATmega2560. Kristal osilator pada Arduino ada yang mempunyai $8 \mathrm{MHz}, 16 \mathrm{MHz}$, dan ada juga yang tergantung dari jenis Arduino. Catu daya untuk mensuplai sistem minimum Arduino cukup dengan tegangan 5 VDC.

Gambar 1 menunjukkan bagian-bagian I/O dari sebuah Arduino. Bagian-bagian tersebut berfungsi sebagai penerima data dari perangkat luar seperti sensor, RTC atau sebagai keluaran hasil proses pengolahan data oleh mikrokontroler yang dapat digunakan sebagai informasi. Arduino juga mempunyai bagian reset yang berfungsi untuk mereset semua data yang telah diolah, sehingga mikrokontroler akan mengulang proses pembacaan data yang diterima dari awal. Fungsi ini juga digunakan untuk mereset program yang sedang berjalan, tujuannya adalah untuk melihat program yang telah dibuat dan di unggah ke Arduino telah sesuai dengan yang diinginkan [5].

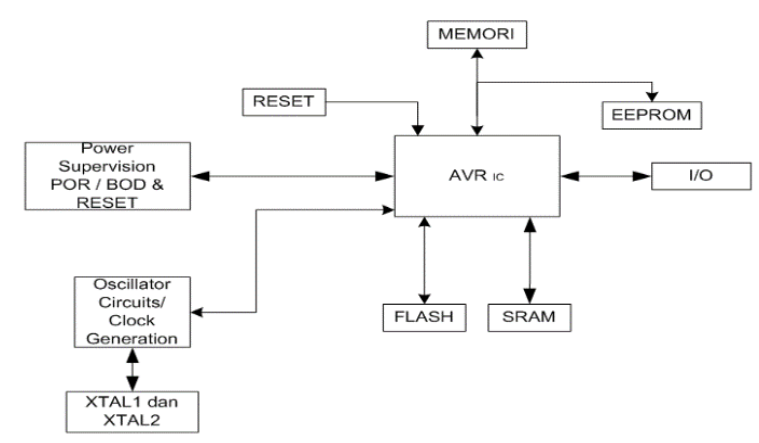

Gambar 1. Blok diagram Arduino

\subsection{Mikrokontroler Atmega 2560}

Mikrokontroler merupakan sebuah chip berupa IC (Integrated Circuit) yang menerima beberapa input, kemudian mikrokontroler mengolah sinyal tersebut dan menghasilkan output sesuai dengan isi program yang ada pada input.

Pada penelitian ini kontroler yang digunakan adalah mikrokontroler ATmega 2560. Mikrokontroler ATmega ini merupakan 
keluarga AVR 8 bit yang didesain oleh Atmel Corporation dan dilengkapi dengan program memori berkapasitas 256 kilobytes. Mikrokontroler ini memiliki arsitektur harvad, yang dapat memisahkan memori-memori, misalnya untuk kode-kode program [6].

Ada beberapa fitur pada ATmega2560 antara lain yaitu:

1. Clock $16 \mathrm{MHz}$ dengan kecepatan mencapai sebesar 16 MIPS.

2. Memiliki tempat penyimpanan data semi permanent yaitu sebesar $4 \mathrm{~KB}$ atau disebut dengan EEPROM (Electricall Erasable Programmable Read Only Memory).

3. Memiliki 54 pin I/O digital, 15 untuk pin PWM (pulse width modulation) output.

4. Memiliki 4 KB SRAM (Static Random Access Memory).

5. Memiliki 4 buah timer/counter 16 bit.

\subsection{RTC}

RTC (Real Time Clock) merupakan chip dengan konsumsi daya rendah. Chip tersebut mempunyai kode binary (BCD), jam/kalender, 56 byte NV SRAM dan komunikasi antarmuka menggunakan serial two wire. RTC menyediakan data dalam bentuk detik, menit, jam, hari, tanggal, bulan, tahun dan informasi yang dapat diprogram. Pada Gambar 2 memperlihatkan konfigurasi dari pin-pin dari RTC [7].

$$
\begin{aligned}
& \text { X1 마뇨 } \\
& \text { X2 } 22 \quad 7 \boxminus \text { SQW/OUT } \\
& \mathrm{V}_{\mathrm{BAT}} \square_{3} \quad 6 \boxminus \mathrm{SCL} \\
& \text { GND } \square 4 \quad 5 \boxminus \mathrm{SDA} \\
& \text { DS1307 8-Pin DIP (300-mil) }
\end{aligned}
$$

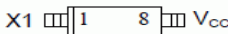

$$
\begin{aligned}
& \text { X2 四 } 24 \text { 四 SQW/OUT } \\
& V_{\text {BAT }} \text { 四 } 3 \quad 6 \text { m } \mathrm{SCL} \\
& \text { GND س } 45 \text { m } 4 \text { SDA } \\
& \text { DS1307 8-Pin SOIC (150-mil) }
\end{aligned}
$$

\section{Gambar 2. Diagram Pin RTC DS1307 [8]}

Fungsi dari Pin DS1307 adalah :

1. VCC digunakan sebagai input dari catu daya 3 volt atau 5 volt.

2. Pin $X 1, X 2$ merupakan pin untuk membuat kristal bekerja dengan frekuensi $32.768 \mathrm{kHz}$.

3. VBAT digunakan sebagai catu daya cadangan ketika arus listrik dari PLN padam

4. GND merupakan negatif dari catu daya

5. SDA digunakan untuk komunikasi serial data antarmuka

6. SCL adalah serial clock

7. SQW/OUT merupakan sinyal keluaran gelombang kotak terprogram (programmable Square Wave).

\section{PERANCANGAN}

Sistem kontrol yang dirancang mampu menyalakan peralatan listrik atau lampu secara acak, serta mampu membedakan kondisi siang dan malam. Tabel 1 memperlihatkan daftar lampu dan peralatan yang akan dikontrol. Terdapat 8 buah lampu dan perangkat elektronik yang akan dikontrol.

Sistem penyalaan adalah acak terhadap semua peralatan. Durasi penyalaan lampu dirancang berbeda-beda sesuai dengan kebiasaan penghuni rumah. Sebagai contoh, lampu kamar mandi (P3) akan meyala selama 15 menit, sedangkan lampu kamar tidur (P2) akan menyala selama 1 jam. Walaupun demikian, durasi penyalaan tersebut hanya merupakan asumsi untuk memudahkan penelitian.

Tabel 1. Daftar perangkat yang dikontrol dan kondisi penyalaan

\begin{tabular}{|l|c|c|c|c|c|}
\hline $\begin{array}{c}\text { Nama Peralatan Listrik } \\
(\mathrm{Pn})\end{array}$ & No & Penyalaan & $\begin{array}{c}\text { L am anya } \\
\text { Penyal aan }\end{array}$ & $\begin{array}{c}\text { L ama Penyalaan } \\
\text { Normalisasi }\end{array}$ & $\begin{array}{c}\text { Waktu } \\
\text { Menyala }\end{array}$ \\
\hline Lampu Luar (P0) & 0 & Acak & 12 Jam & 720 Detik & Malam \\
\hline Lampu Ruang Keluarga (P1) & 1 & Acak & 1 Jam & 60 Detik & Malam \\
\hline Lampu Kamar Tidur (P2) & 2 & Acak & 1 Jam & 60 Detik & Malam \\
\hline Lampu Kamar Mandi (P3) & 3 & Acak & 15 Menit & 15 Detik & Malam \\
\hline Lampu Dapur (P4) & 4 & Acak & 30 Menit & 30 Detik & Malam \\
\hline Lampu Ruang Makan(P5) & 5 & Acak & 30 Menit & 30 Detik & Malam \\
\hline TV (P6) & 6 & Acak & 1 Jam & 60 Detik & 24 Jam \\
\hline Tape Recorder (P7) & 7 & Acak & 20 Menit & 20 Detik & 24 Jam \\
\hline
\end{tabular}

Sistem dirancang untuk dapat membedakan siang dan malam. Hal ini bertujuan untuk memilih peralatan atau lampu mana saja yang boleh menyala pada siang atau malam hari. Tabel 1 juga memperlihatkan normalisai waktu yang diperbolehkan bagi setiap peralatan untuk menyala. Proses normalisasi ini bertujuan untuk memudahkan perekaman proses penyalaan dalam durasi yang cukup lama (beberapa hari). Sebagai contoh lampu yang seharusnya menyala 15 menit akan dinormalisasi menjadi hanya 15 detik. 


\subsection{Perancangan Hardware}

Gambar 3 merupakan rancangan sistem kontrol penyalaan peralatan listrik rumah tangga secara acak. Semua peralatan listrik dikontrol oleh Arduino dengan cara mengaktifkan driver relay. Ada beberapa bagian blok pada gambar perancangan seperti catu daya, sistem kontrol, driver relay dan juga peralatan listrik yang dikontrol.

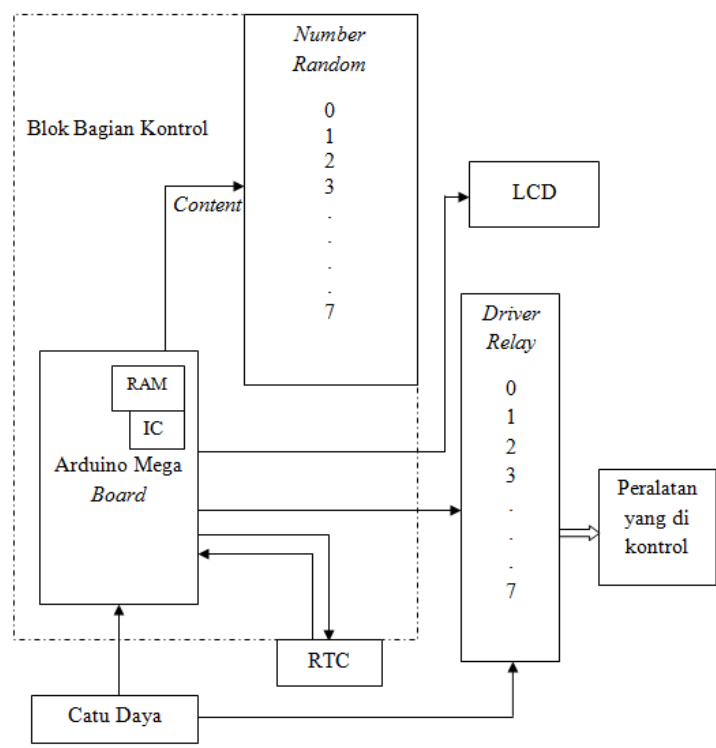

Gambar 3. Diagram blok system

Catu daya sebagai sumber untuk mengaktifkan Arduino, kemudian Arduino membangkitkan bilangan random. Ada 8 bilangan random diprogram, setiap bilangan random dibangkitkan tersebut menjadi input untuk driver relay. Ketika driver relay menerima input dari Arduino maka driver relay aktif dan menyalakan peralatan listrik sesuai dengan bilangan random.

Mikrokontroler pada Arduino mensetting RTC untuk menjalankan jam, menit, detik, tanggal, bulan dan tahun. Kemudian data tersebut digunakan oleh ardunio sebagai data base peralatan listrik dan bilangan random. RTC digunakan untuk membedakan penyalaan listrik pada malam hari dan siang hari, sehingga tidak ada lampu yang nyala pada siang harinya. Selain itu digunakan untuk membuat program peralatan listrik (TV dan Tape Recorder) menyala sesuai dengan kondisi khusus, seperti saat azan, dan waktu-waktu yang digunakan untuk beristirahat. Sehingga tidak mengganggu orang yang tinggal di sekitar rumah tersebut.
LCD atau monitor digunakan untuk melihat peralatan listrik apa saja yang sedang menyala. selain itu digunakan untuk melihat tampilan interval dan waktu yang sedang berjalan. Monitor ini digunakan hanya untuk memudahkan mengecek sistem kontrol atau sistem keamanan jika sistem berjalan tidak sesuai dengan yang diharapkan.

Driver relay pada sistem kontrol tersebut memanfaatkan 8 buah relay untuk mengontrol peralatan listrik. Setiap rangkaian driver relay terdiri dari satu buah transistor jenis PNP dan sebuah relay. Fungsi dari transistor ini adalah sebagai pemicu untuk mengubah kontak-kontak relay dari NO (normally open) menjadi close (tersambung) atau NC (normally close) menjadi open (terbuka). Gambar 4 menunjukkan rangkaian detail sebuah driver relay.

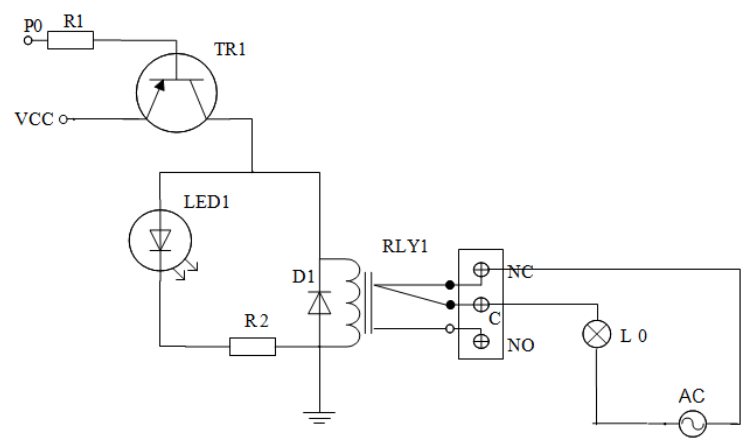

Gambar 4. Rangkaian driver relay untuk pengontrolan peralatan listrik

\subsection{Perancangan Software}

Blok diagram Gambar 5 merupakan alur dan sistem kerja dari software sistem keamanan saat melakukan pengontrolan penyalaan peralatan listrik. Pada saat sistem dijalankan, program menunggu selama 15 menit dan kemudian membangkitkan sebuah bilangan random. Setelah bilangan random dibangkitkan, sistem mulai membaca data base daftar peralatan untuk menentukan lamanya suatu peralatan menyala. Kemudian bilangan random yang dibangkitkan untuk meyalakan peralatan listrik pada malam hari, maka sistem akan mengecek apakah saat ini malam atau siang.

Selanjutnya, sistem akan memutuskan apakah peralatan dinyalakan atau tidak. Jika peralatan dinyalakan maka peralatan tersebut akan padam kembali pada saat nilai intervalnya tercapai. Sistem yang diprogram terus berjalan dan terus-menerus membangkitkan bilangan 
random, karena sistem diprogram secara looping. Sistem akan mati dan tidak membangkitkan bilangan random ketika catu dayanya dilepas atau sistemnya dimatikan.

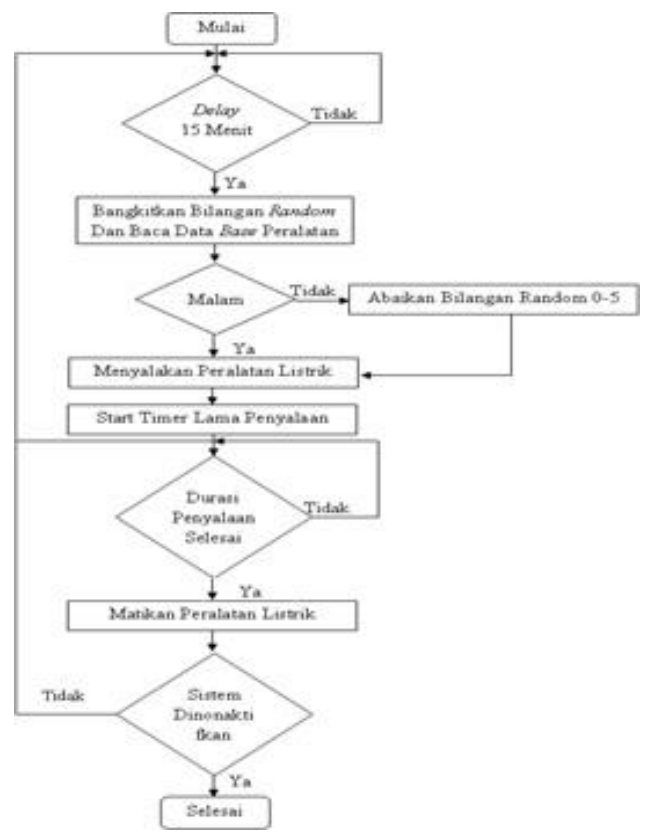

Gambar 5. Diagram blok tahap pengontrolan peralatan listrik.

\section{HASIL DAN PEMBAHASAN}

Untuk menguji performa dari sistem yang dirancang, dilakukan pengetesan terhadap sistem kontrol dan pengujian terhadap peralatan listrik secara langsung.

\subsection{Pengetesan Sistem Kontrol}

Sistem kontrol yang telah dirancang (baik hardware maupun software) di uji dengan menambahkan LED sebagai penanda ouput. Delapan buah LED digunakan untuk mewakili semua peralatan listrik termasuk TV dan Tape recorder. Daftar semua peralatan yang dikontrol dapat dilihat pada Tabel 1.

Setiap bilangan acak yang diprogram berisi nama perangkat listrik dan intervalnya. Seperti pada Gambar 6 dimana terlihat saat jam menunjukkan detik 30, maka sistem mulai membangkitkan sebuah bilangan acak. Saat pertama kali muncul bilangan acak, yang terlihat adalah nilai intervalnya sudah sangat jauh dari batas penyalaan yang seharusnya. Dapat dilihat pada Gambar 6 nilai intervalnya sudah mencapai 134, sedangkan batas untuk penyalaan LED 7 adalah 20. Sehingga walaupun sistem telah membangkitkan bilangan 7, tetapi LED 7 belum menyala. LED-LED yang menyala pada saat nomor acak 7 dibangkitkan adalah LED nomor acak 0 dan 2.

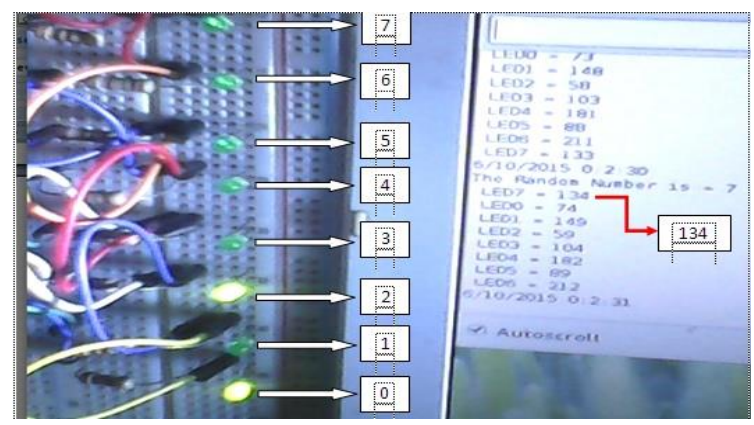

Gambar 6. Sistem membangkitkan bilangan random angka 7

Setiap sistem membangkitkan bilangan acak ketika sistem telah lama aktif, maka nilai interval bilangan acak yang dibangkitkan pasti sudah melebihi batas penyalaannya. Nilai interval tersebut kemudian direset saat detik selanjutnya, sehingga nilai interval tersebut menjadi nol dan peralatan listrik pun menyala. Seperti pada Gambar 7 ada kotak dengan tanda panah merah dan isi di dalam kotak pertama adalah 0 dan kotak ke dua adalah 1 . Nilai-nilai tersebut menandakan sistem sedang membaca nilai interval dari peralatan nomor acak 7 .

Ketika LED 7 mulai menyala, terlihat LED dengan nomor acak 2 telah padam. LED tersebut padam karena batas intervalnya telah tercapai, seperti terlihat pada gambar bagian tampilan monitor IDE. Pada bagian tersebut terlihat nilai interval LED $2=61$ dan diketahui bahwa nilai interval dari peralatan nomor acak 2 adalah 60 detik.

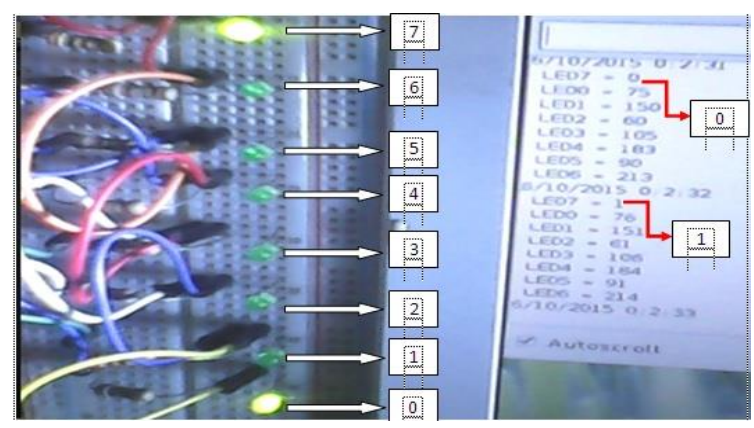

Gambar 7. Reset interval bilangan 7 agar LED nomor 7 menyala 
Pada Gambar 8 menunjukkan tampilan layar monitor IDE, dimana terlihat ada kotak dengan tanda panah warna merah dengan nilai 21 dan 22. Nilai ini adalah nilai dari interval LED 7 (padam). LED dengan nomor acak 0 terlihat masih terus menyala dari mulai Gambar 6-8, karena nilai intervalnya belum tercapai, nilai intervalnya adalah 720 detik. Ketika LED 7 padam nilai intervalnya sudah mencapai 96 dan masih jauh dari batas lama penyalaannya. Sistem telah membangkitkan bilangan acak saat tercapai delay selama 15 menit dan yang muncul adalah bilangan acak 2. Sehingga LED dengan nomor acak 2 telah menyala kembali.

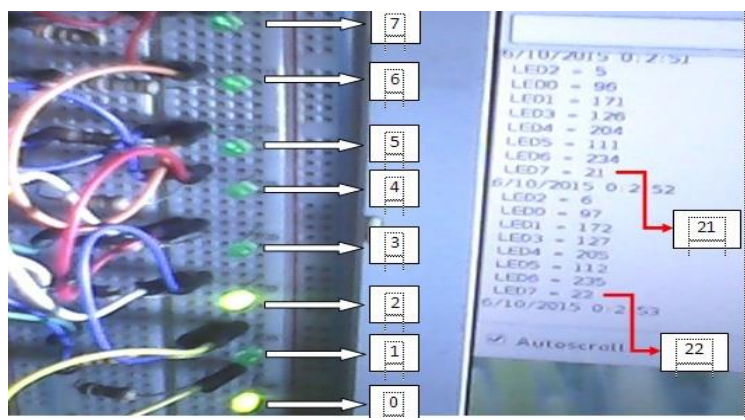

Gambar 8. Kondisi saat LED 7 padam lagi

Pengujian sistem dilakukan selama 2 jam waktu normalisasi yang mewakili 5 hari waktu normal. Ketika sistem diaktifkan sistem mulai menghitung nilai tunda untuk membangkitkan bilangan acak. Setiap bilangan acak yang dibangkitkan, beserta data base peralatan listriknya tersebut ditampilkan pada LCD.

Pada pengujian ini, sebagian bilangan acak yang dibangkitkan diabaikan oleh sistem karena nilai interval yang belum tercapai. Sehingga bilangan acak ini harus ditandai untuk memudahkan dalam memisahkan data bilangan acak yang tidak diabaikan dengan yang diabaikan. Cara menandai bilangan tersebut dengan mencatat nilai bilangannya beserta jam, menit, dan detik saat bilangan acak dibangkitkan. Tampilan monitor memberikan keterangan kondisi siang atau malam. Angka yang ditampilkan adalah 1-12 atau 13-24, begitu juga untuk setiap harinya.

\subsection{Pengetesan Sistem dengan Miniatur Rumah}

Untuk memberikan gambaran yang lebih jelas terhadap pengujian sistem, dirancang sebuah rumah miniatur. Rumah tersebut telah dilengkapi dengan peralatan listrik seperti yang telah diprogram sebelumnya. Gambar 9 memperlihatkan tampilan saat pengetesan kondisi malam hari. Pada kondisi tersebut, terlihat lampu luar rumah (P0) menyala.

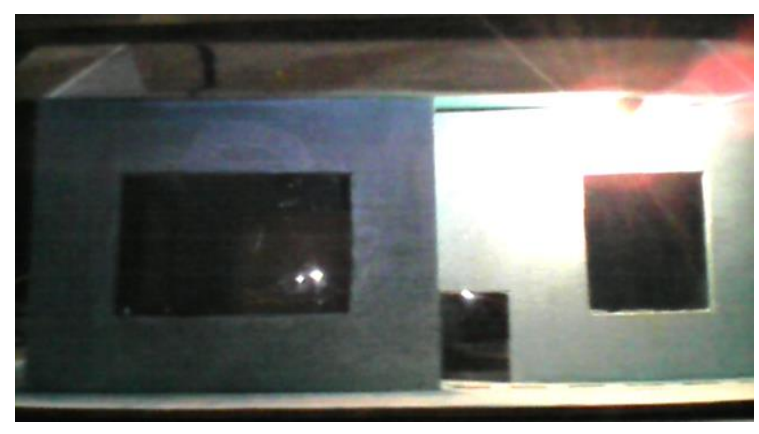

Gambar 9. Tampilan saat sistem baru diaktifkan (malam hari)

Sistem juga diuji dengan semua kondisi (waktu) seperti yang telah dilakukan terhadap pengujian sistem kontrol. Gambar 10 menampilkan kondisi rumah miniatur saat malam hari dengan beberapa lampu yang menyala (lampu luar dan lampu di dalam rumah).

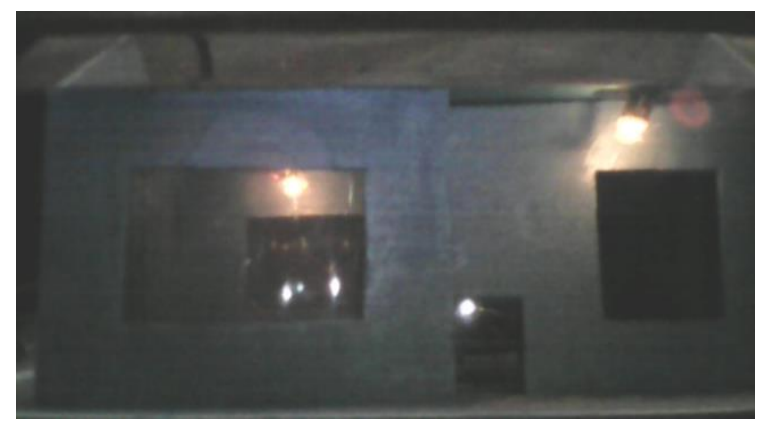

Gambar 10. Tampilan rumah saat sistem bekerja (malam hari)

\subsection{Perkiraan Kebutuhan Daya Listrik}

Data-data yang didapatkan selam sistem bekerja dipisahkan untuk setiap harinya agar mudah melihat berapa kali terjadinya penyalaan (Tabel 2). Data yang diperoleh digunakan untuk mengetahui tingkat efesiensi dari sistem, karena data yang didapat berupa pemakaian daya yang digunakan selama terjadi penyalaan peralatan listrik. Daya yang digunakan selama pengujian sistem dapat dihitung dalam $\mathrm{kWh}$ (Kilo Watt Hours). Untuk menganalisa daya yang terpakai oleh sistem digunakan persamaan (1). Data 
selengkapnya ditunjukkan pada Tabel 2.

$\mathrm{kWh}=$ watt $\mathrm{x} \mathrm{k} \mathrm{x} \mathrm{hours} / 1000$

Dimana $\mathrm{k}$ adalah jumlah terjadinya penyalaan peralatan listrik.

Tabel 2. Data pengujian sistem selama 5 hari dan estimasi kebutuhan daya

\begin{tabular}{|c|c|c|c|c|c|c|c|}
\hline \multirow[t]{2}{*}{$\begin{array}{c}\text { Peralatan } \\
\text { Listrik }\end{array}$} & \multicolumn{5}{|c|}{$\begin{array}{c}\text { Jumlah Terjadi Penyalaan } \\
\text { Listrik selama } 24 \text { Jam } \\
\text { (Hari ke) }\end{array}$} & \multirow[t]{2}{*}{ Daya } & \multirow[t]{2}{*}{$\begin{array}{c}\text { Jumlah Daya } \\
\text { Terpakai } \\
\text { (kWh) }\end{array}$} \\
\hline & I & II & III & IV & $\mathrm{V}$ & & \\
\hline $\mathrm{P} 0$ & 1 & 1 & 1 & 1 & 1 & 2 Watt & 0,12 \\
\hline P1 & 4 & 4 & 3 & 4 & 3 & 7 Watt & 0,13 \\
\hline P2 & 4 & 4 & 2 & 2 & 4 & 7 watt & 0,11 \\
\hline P3 & 5 & 7 & 7 & 7 & 5 & 2 Watt & 0,02 \\
\hline P4 & 5 & 5 & 5 & 6 & 6 & 2 Watt & 0,03 \\
\hline P5 & 4 & 7 & 7 & 4 & 5 & 5 Watt & 0,07 \\
\hline P6 & 8 & 7 & 7 & 9 & 9 & 30 Watt & 1,20 \\
\hline P7 & 10 & 8 & 9 & 9 & 8 & 30 Watt & 0,44 \\
\hline \multicolumn{7}{|c|}{ Total daya yang terpakai selama 5 hari } & 2,12 \\
\hline \multicolumn{7}{|c|}{ Daya rata-rata per hari } & 0,42 \\
\hline
\end{tabular}

Tabel 2 menampilkan data jumlah terjadi penyalaan, misal hari ke I untuk setiap peralatan listriknya (P0-P7) mempunyai angka tersendiri. Angka tersebut mempunyai makna jumlah penyalaan, seperti $\mathrm{P} 7$ yang mempunyai angka 10 pada hari ke I. Hal ini merupakan jumlah penyalaan P7 selama sehari adalah 10 kali.

Tabel juga memperlihatkan perhitungan perkiraan konsumsi daya dari sistem yang dirancang selam 5 hari pengujian. Daya per hari berbeda-beda, tergantung dari keacakan proses penyalaan peralatan listrik. Daya total selama pengujian adalah $2,12 \mathrm{kWh}$ atau daya rata-rata perhari adalah sebesar 0,42 $\mathrm{kWh}$. Sehingga kebutuhan biaya listrik per hari oleh sistem ini adalah Rp 636 (asusmsi $1 \mathrm{kWh}=\mathrm{Rp} .1500$ ).

\section{KESIMPULAN}

Sistem kontrol penyalaan lampu dan perangkat elektronik telah berhasil dibuat. Sistem tersebut mampu meniru keberadaan penghuni rumah saat rumah ditinggalkan. Sistem dirancang dengan Arduino, dilengkapi dengan RTC, catu daya dan interface perantara dengan rumah miniatur.

Sistem diprogram untuk membangkitkan bilangan acak setiap 15 menit. Peralatan listrik yang telah menyala akan padam ketika nilai intervalnya tercapai. Pengujian sistem selama 5 hari dilakukan dengan normalisasi menjadi 2 jam. Penggunaan daya cukup efisien, kira-kira $0,42 \mathrm{kWh}$ per hari.

\section{DAFTAR PUSTAKA}

[1] Junaedi, Iskandar. (2007). Perancangan dan Realisasi Pengaturan Lampu Rumah Tinggal Melalui Saluran Telepon Menggunakan Pengendali Mikro At89c2051r. Jurnal Rekayasa dan Teknologi Elektro, Volume 1 No.1 Edisi September 2007.

[2] Dwi Astiyana. (2011). Perancangan Aplikasi Pengendali Lampu Ruangan Berbasis Sms Gateway Dengan Mikrokontroler; [diakses tanggal 16 Desember 2014]. tersedia pada:

http://repository.amikom.ac.id/files/Publi kasi_07.11.1578.pdf

[3] Irwan Dinata dan Wahri Sunanda (2015). "Implementasi Wireless Monitoring Energi Listrik Berbasis Web Database", Jurnal Nasional Teknik Elektro Vol. 4, No. 1. Maret 2015

[4] Riani L. (2010). Pemabngkitan Bilangan Acak; [diakses tanggal 15 November 2015]. tersedia pada:

http://elib.unikom.ac.id/files/disk1/471/jb ptunikompp-gdl-rianilubis-23527-5-

06rando-r.pdf

[5] W.Evans, Brian. (2007). Arduino Programming Notebook. San Francisco: Penerbit First Edition.

[6] Kadir, Abdul. (2008). Panduan Praktis Mempelajari Aplikasi Mikrokontroler dan Pemogramannya Menggunakan Arduino. Yogyakarta: Penerbit Andi.

[7] Hartika Zain, Ruri. (2013). Sistem Keamanan Ruangan Menggunakan Sensor Passive Infra Red (PIR) Dilengkapi Kontrol Penerangan Pada Ruangan Berbasis Mikrokontroler ATmega8535 Dan Real Time Clock.Jurnal Teknolog iinformasi \& pendidikan, Vol.6 No. 1 Maret 2013 ISSN: 2086-4981

[8] Agfianto Eko Putra Cert. NNLP Pract. (2009). Tutorial AT89: RTC DS1307 (64 x 8 Serial Real-Time Clock); [diakses tanggal 31 Desember 2014]. tersedia pada:

http://agfi.staff.ugm.ac.id/blog/index.php/ 2009/02/tutorial-at89-rtc-ds1307-64-x-8serial-real-time-clock/. 


\section{Biodata Penulis}

Zulfikar, Lahir di Beureunuen, Aceh, Indonesia, pada tahun 1975. Dia menerima gelar sarjana dalam bidang Teknik Elektro dari Universitas Sumatera Utara, Medan, Indonesia, pada tahun 1999. Kemudian gelar magister dari King Saud University, Riyadh Saudi Arabia tahun 2011. Dia bergabung sebagai tenaga pengajar pada Jurusan Elektronika di Politeknik Caltex Riau pada tahun 2003. Dia telah menjadi kepala laboratorium Kontrol Industri selama tiga tahun dari 2003 sampai 2006. Pada tahun 2006, Dia bergabung dengan Jurusan Teknik Elektro Universitas Syiah Kuala sebagai staf pengajar. Saat ini dia aktif menekuni riset dalam bidang desain VLSI dan Systems on Chips (SoC).

Zulhelmi, Lahir pada tahun 1979 di Gigieng Simpang Tiga, yang berlokasi di kabupaten Pidie propinsi Aceh. Dia mendapatkan gelar sarjana dari Universitas Syiah Kuala, BandaAceh, Indonesia pada tahun 2003. Kemudian gelar Magister dalam bidang Teknik Elektro dari King Saud University, Riyadh Saudi Arabia tahun 2013. Dia telah mengajar pada Jurusan Teknik Elektro Universitas Syiah Kuala sejak tahun 2003. Riset yang yang ditekuni termasuk desain elektronik, desain dan implementasi arsitektur dengan FPGA, desain arsitektur VLSI, dan aritmatika komputer.

Khairul Amri, Lahir pada tahun 1991 di Suka Makmu, yang berlokasi di kabupaten Bireuen propinsi Aceh. Dia mendapatkan gelar sarjana dari Universitas Syiah Kuala, Banda Aceh, Indonesia pada tahun 2016. Selama menempuh pendidikan, dia aktif melakukan riset pemamfaatan bilangan random dengan Arduino. Dia telah mengajar pada Jurusan Teknik Elektro. 